\title{
An unusual presentation of metastatic squamous cell cervical carcinoma involving the distal ileum mimicking Crohn's disease
}

ERIC M YOSHIDA MD FRCPC, HUGH CHAUN BM FRCPC, KENNETH D SWENERTON MD FRCPC, KENNETH W BEREAN MD FRCPC, GREGOR I MCGREGOR MD FRCSC

EM YoSHIDA, H CHAUN, KD SWENERTON, KW BEREAN, GI MCGREGOR. An unusual presentation of metastatic squamous cell cervical carcinoma involving the distal ileum mimicking Crohn's disease. Can J Gastroenterol $1994 ; 8(5): 323-325$. Both primary and secondary malignant diseases may present with a clinical, radiological and/or endoscopic picture resembling Crohn's disease. In this report, a 64-year-old woman previously treated surgically and with radiation for stage I B squamous cell carcinoma of the cervix presented with diarrhea and had endoscopic findings simulating Crohn's disease. Biopsies and subsequent laparotomy revealed that the lesions were metastatic cervical carcinoma involving the terminal ileum.

Key Words: Carcinoma, Cervical, Crohn's disease, Ileum, Metastatic

\section{Tableau clinique inhabituel d'un cancer du col métastatique à} cellules squameuses affectant l'iléon distal et évocateur d'une maladie de Crohn

RÉSUMÉ : Les néoplasies primaires et secondaires peuvent se présenter sous la forme d'un tableau clinique, radiologique ou endoscopique ressemblant à la maladie de Crohn. Dans ce rapport, une femme de 64 ans, traitée auparavant chirurgicalement et par irradiation pour un cancer du col à cellules squameuses de stade B1, s'est présentée avec de la diarrhée et des signes endoscopiques évocateurs de la maladie de Crohn. Les biopsies et la laparotomie subséquentes ont révélé que les lésions étaient des métastases de son cancer du col ayant atteint l'iléon terminal.

Departments of Medicine, Pathology and Surgery, University of British Columbia,

Vancouver, British Columbia

Correspondence and reprints: Dr Hugh Chaun, 601-805 West Broadway, Vancouver, British Columbia V5Z 1K1. Telephone (604) 872-0717, Fax (604) 872-7921

Received for publication February 8, 1994. Accepted March 15, 1994
TNVASIVE CARCINOMA OF THE UTERIne cervix is the third most frequent genital cancer among females (1). The time interval from carcinoma in situ to invasive cancer varies but 30 to $71 \%$ of untreated patients will develop invasive cancer 10 to 12 years after the development of carcinoma in situ (2). Metastatic spread is usually lymphatic to regional then para-iliac and aortic nodes. Hematogenous metastases are uncommon but have been reported to occur in bone (3), lung (4), pericardium and myocardium $(5,6)$, kidney (7), brain (8) and skin (9). In the gastrointestinal tract, metastatic disease has been described in the small intestine $(10,11)$, most likely from lymphatic spread although one report of ileocecal metastasis was attributed, perhaps erroneously, to hematogenous seeding (12). Possible hematogenous spread to the colon (13) and liver (14) has been reported. Small bowel metastases have usually presented with obstructive symptoms. In this report, a patient with an isolated distal ileal metastasis from cervical carcinoma had endoscopic findings resembling 


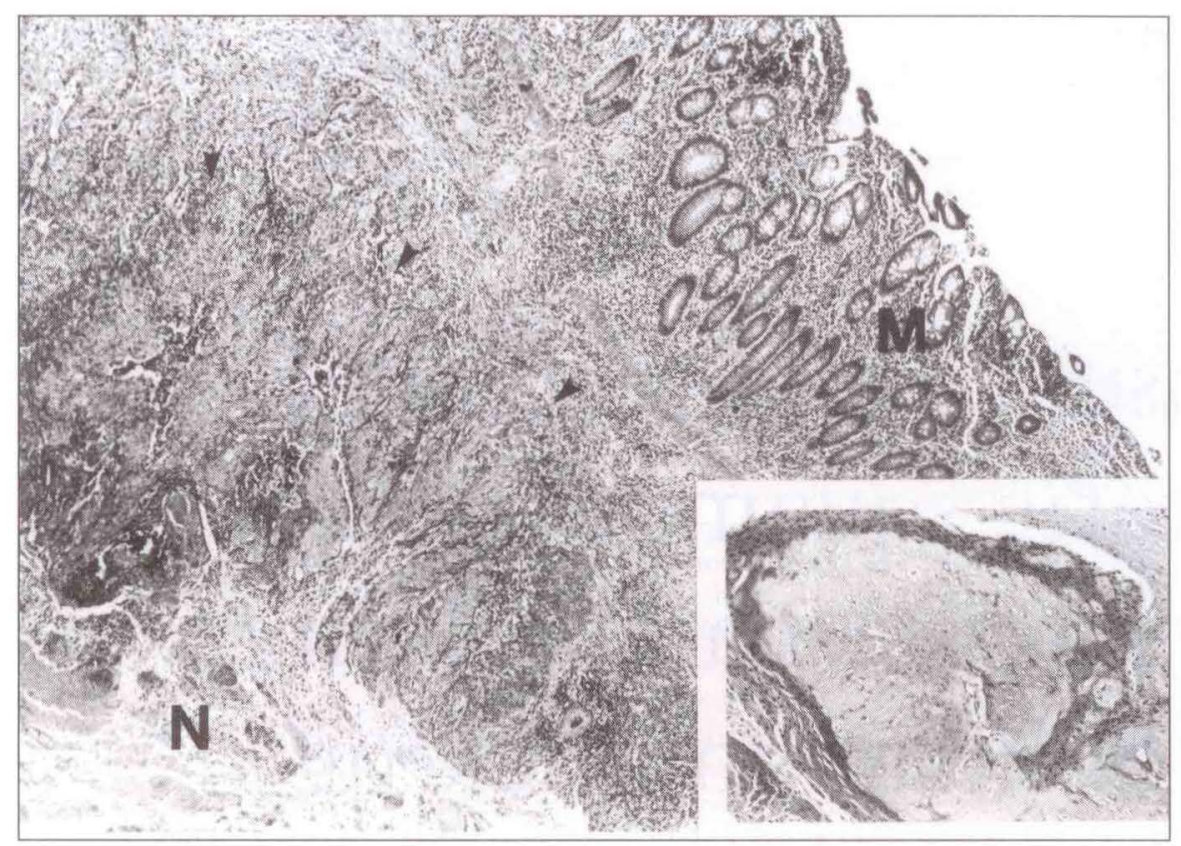

Figure 1) Right hemicolectomy specimen showing metastatic squamous cell carcinoma (arrowheads) from the uterine cervix. The tumour is present in the submucosa with intact overlying mucosa (M), although ulceration was present in sections taken from other regions. The central portion of the tumour is necrotic $(\mathrm{N})$. Inset shows keratinizing squamous cell carcinoma

Crohn's disease. A Crohn's-like presentation of cervical carcinoma has not been reported before.

\section{CASE PRESENTATION}

Two years previously, a 64-year-old Caucasian woman had undergone radical hysterectomy and pelvic lymphadenectomy followed by a full course of pelvic radiation therapy for invasive stage I B squamous cell carcinoma of the cervix. The patient experienced diarrhea during radiation therapy which resolved after the radiation was completed. One year later the diarrhea recurred but was nonbloody. One month before presentation, she noted streaks of blood in the stools. She also complained of occasional intermittent periumbilical pain which predated her hysterectomy and occurred about once every one to two months. Apart from a previous appendectomy, there was no history of gastrointestinal disease. An upper gastrointestinal series performed six years previously was unremarkable. There was no family history of inflammatory bowel disease. Physical examination, including bimanual examination of the pelvis, was unremarkable. A Papanicolaou smear for cytology was negative. The hematological profile and liver enzymes were normal as were radiographs of the chest. A computed tomography scan of the abdomen and pelvis just before presentation did not demonstrate any evidence of recurrent disease.

At colonoscopy, the ileocecal valve was hyperemic and unusually prominent. There was a mucus exudate overlying hyperemic mucosa in the terminal ileum. Biopsies were taken of these areas. The rest of the examination was normal. The findings at colonoscopy were suggestive of Crohn's disease of the distal ileum. Histopathological examination of the biopsies, however, revealed an infiltrating, moderately differentiated squamous cell carcinoma of the terminal ileum and ileocecal valve, consistent with metastatic squamous cell carcinoma of the cervix, with a surrounding inflammation. There was no evidence of vascular invasion.

A right hemicolectomy was undertaken. At surgery there was thickening of the terminal ileum consistent with previous irradiation and an isolated firm nodule; there was no other evidence of intraperitoneal malignancy.
The resected right hemicolectomy specimen measured $57 \mathrm{~cm}$ in length and consisted of $40 \mathrm{~cm}$ of distal ileum and $17 \mathrm{~cm}$ of cecum and ascending $\mathrm{co}^{-}$ lon. A firm grey-white circumferential lesion with areas of necrosis was present in the terminal ileum. Histological examination of this lesion showed moderately differentiated squamous cell carcinoma involving the full thickness of bowel wall (Figure 1). The tumour was histologically identical to the primary cervical cancer. One mesenteric lymph node adjacent to the tumour was replaced by mesenteric squamous cell carcinoma. The rest of the mucosa did not reveal evidence of inflammatory bowel disease. Abdominal ultrasonography postoperatively was unremarkable.

\section{DISCUSSION}

This patient had colonoscopic findings consistent with Crohn's disease. Biopsies of the distal ileum, however, revealed metastatic squamous cell carcinoma with surrounding inflammation. The metastatic lesion was confined to the terminal ileum; the rest of the distal ileum was thickened, attributed to previous radiotherapy. Crohn's disease is a chronic inflammatory disorder of unknown etiology. The age distribution is bimodal with peaks in young adulthood and in the sixth to ninth decades (15). Any part of the gastrointestinal tract may be affected. At least three-quarters of patients have involvement of the small intestine, of which $90 \%$ involve the terminal ileum (16). Although granulomata are characteristic of Crohn's disease, they are seen in less than $50 \%$ of cases (16). Their absence does not exclude a diagnosis of Crohn's disease. On the other hand, many other conditions of known etiology can appear similar to idiopathic Crohn's disease, the most well recognized being infectious diseases with mycobacterial, bacterial (eg, yersinia enteritis) and viral (eg, cytomegalovirus in immunosuppressed patients [17]) pathogens.

As in our patient, neoplastic disease and/or sequelae of treatment may resemble Crohn's disease clinically and radiologically $(18,19)$. Both primary 
and secondary malignancies have been reported to mimic Crohn's disease. Locally invasive adenocarcinoma of the colon has, radiologically, been mistaken for Crohn's disease (20), as has primary adenocarcinoma of the ileocecal region $(18,20)$. Carcinoid tumours $(18,19,21)$ and lymphomas, both Hodgkin's (18) and non-Hodgkin's (22), have also been reported to simulate Crohn's enteritis and colitis, respectively. There have been reports of primary malignancies, including lung (23), melanoma (24), thyroid (25) and hepatocellular carcinoma (26), metastasizing to the ileum and jejunum. For the most part, these secondary tumours have been clinically distinguishable from Crohn's disease. Other metastatic lesions to the small intestine, however, have been reported to mimic Crohn's

\section{REFERENCES}

1. Silverberg E, Boring CC, Squires TS. Cancer statistics. CA 1990;40:9-26.

2. Hoskins WJ, Perez CA, Young RC. Gynecologic tumours in cancer. In: DeVita VT Jr, Hellman S, Rosenberg $\mathrm{SA}$, eds. Cancer. Principles and Practice of Oncology, 4th edn. Philadelphia: Lippincott Co, 1993:1152-225.

3. Singhal S, De S, Chander S, Rath GK. Skeletal metastases in carcinoma of the uterine cervix - a report of two cases and review of the literature. Indian J Med Sci 1990,44:179-82.

4. Lipmann MC, Goldberg SK, Smith HI, Eliraz A. Pulmonary metastases from cancer of the cervix. Israel J Med Sci 1992;28:743-6.

5. Nelson BE, Rose PG. Malignant pericardial effusion from squamous cell cancer of the cervix. J Surg Oncol 1993;52:203-6.

6. Kountz DS. Isolated cardiac metastasis from cervical carcinoma: Presentation as anteroseptal myocardial infarction. South Med J 1993;86:228-30.

7. Koike H, Okamoto T, Tanji S, et al. Two cases of metastatic renal tumor. Hinyokika Kiyo 1989;35:455-9. (Japanese)

3. Kumar L, Tanwar RK, Singh SF Intracranial metastases from cervical cancer and review of the literature. Gynecol Oncol 1992;46:391-2.

9. Hayes AG, Berry AD III. Cutaneous metastasis from squamous cell cancer of the cervix. J Am Acad Dermatol 1992;26(Part 2):846-50.

10. DeCastro CA, Dockerty MB, Mayo CW. Metastatic tumours of the small intestines. Surg Gynec Obstet 1957;105:159-65.

11. Farmer RG, Hawk WA. Metastatic tumours of the small bowel. Gastroenterology 1964;47:496-504. disease. In particular, this has been described with metastatic lesions from the breast $(18,27,28)$ and stomach $(29,30)$. In a 1989 review (31) there were 13 cases of breast cancer and five cases of gastric cancer that mimicked Crohn's disease reported over almost 30 years. Twelve of these cases involved the terminal ileum. The sequelae of oncological therapy, specifically radiation, may also result in an endoscopic (32) and radiological (33) picture resembling Crohn's disease.

The endoscopic features noted in our patient's distal ileum were suggestive of Crohn's disease. Similar findings have been described previously with other malignancies $(18,22,29)$. Interestingly, in one report of linitis plastica of the sigmoid colon, initial endoscopic biopsies revealed acute and chronic in-

12. de Jode LR. A case of metastatic carcinoma of the ileocaecal valve presenting as a primary growth. Br J Surg 1959;46:505-6.

13. McMahon AJ. Squamous carcinoma of the colon: Primary or metastatic? Eur J Surg Oncol 1991;17:397-402.

14. Herbst AL. Malignant diseases of the cervix. In: Herbst AL, Mishell DR, Stenheuer MA, Droegemueller S, eds. Comprehensive Gynecology, 2nd edn. St Louis: Mosby Year Book Inc, 1992:861-94.

15. Grimm IS, Friedman LS. Inflammatory bowel disease in the elderly. Gastroenterol Clin North Am 1990;19:361-89.

16. Kornbluth A, Saloman P, Sachar DB. Crohn's disease. In: Sleisenger MH, Fordtran JS, eds. Gastrointestinal Disease. Pathophysiology, Diagnosis, Management, 5th edn. Philadelphia: WB Saunders Co, 1993:1270-304.

17. Wajsman R, Cappell MS, Biempica L, et al. Terminal ileitis associated with cytomegalovirus infection and the acquired immune deficiency syndrome. Am J Gastroenterol 1989;84:790-3.

18. Lavy A, Militianu D, Eidelman S. Diseases of the intestine mimicking Crohn's disease. J Clin Gastroenterol 1992;15:17-23.

19. Badley AD, MacCormick RE, Lebrun GP. Neoplastic imitators of small bowel Crohn's disease. Can J Gastroenterol 1992;6:77-83.

20. Andreson JL, Banks PA. Tumor of the ileocecal region; differentiation from Crohn's disease. Am J Gastroenterol 1982;77:910-2.

21. Mir-Madjlessi SH, Winkleman EI, Davis GA. Carcinoid tumours of the terminal ileum simulating Crohn's disease. Cleve Clin J Med 1988;55:257-62.

22. Weir AB, Poon MC, Groarke JF, flammation only, which seemed to confirm a diagnosis of Crohn's colitis (18). The authors felt that, in retrospect, the inflammatory changes were reactive to the malignant process. In our patient, although it is possible that the endoscopic changes seen were due to radiation enteritis, biopsies of the involved area demonstrated infiltrating squamous cell carcinoma. Like the other cases, we feel that the endoscopic features of our patient were secondary to the malignancy.

In conclusion, this case of a patient with an isolated metastatic cervical cancer of the terminal ileum presenting as Crohn's disease underlines the need to consider neoplastic disease in the differential diagnosis of apparent inflammatory bowel disease and a history of previous malignancy.

Wilkerson JA. Lymphoma simulating Crohn's colitis. Dig Dis Sci 1980;25:69-72

23. McNeill PM, Wagman LD, Neifeld JP. Small bowel metastases from primary carcinoma of the lung. Cancer 1987;59:1486-9.

24. Ihde JK, Colt DG. Melanoma metastatic to stomach, small bowel, or colon. Am J Surg 1991;162:208-11.

25. Phillips DL, Benner KG, Keeffe EB, Traweek $T$. Isolated metastasis to small bowel from anaplastic thyroid carcinoma. J Clin Gastroenterol 1987;9:563-7.

26. Yang PM, Sheu JC, Yang THL, et al. Metastasis of hepatocellular carcinoma to the proximal jejunum manifested by occult gastrointestinal bleeding. Am J Gastroenterol 1987;82:165-7.

27. Weisberg A. Metastatic adenocarcinoma of the breast masquerading as Crohn's disease of the colon. Am J Proctol Gastro Colon Rect Surg 1982;33:10,11,14,15,22.

28. Koos L, Field RE. Metastatic carcinoma of breast simulating Crohn's disease. Int Surg 1980;4:359-62.

29. Katon RM, Brendler SJ, Ireland K. Gastric linitis plastica with metastases to the colon; a mimic of Crohn's disease. J Clin Gastroenterol 1989;11:555-60.

30. Kwan WCP, Freeman HJ. Signet ring cell carcinoma of the colon radiologically simulating ileocecal tuberculosis. Can J Gastroenterol 1992;6:341-4

31. Madeya S, Borsch G. Differential diagnosis of Crohn's disease: Segmental intestinal metastasis of breast and stomach cancer. Leber Magen Darm 1989;19:140,143-6, 149-52. (German)

32. Reichelderfer M, Morrisey JF. Colonoscopy in radiation colitis. Gastrointest Endosc 1980;26:41-3

33. Mendelson RM, Nolan DJ. The radiological features of chronic radiation enteritis. Clin Radiol 1985;36:141-8. 


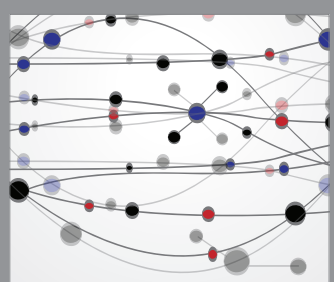

The Scientific World Journal
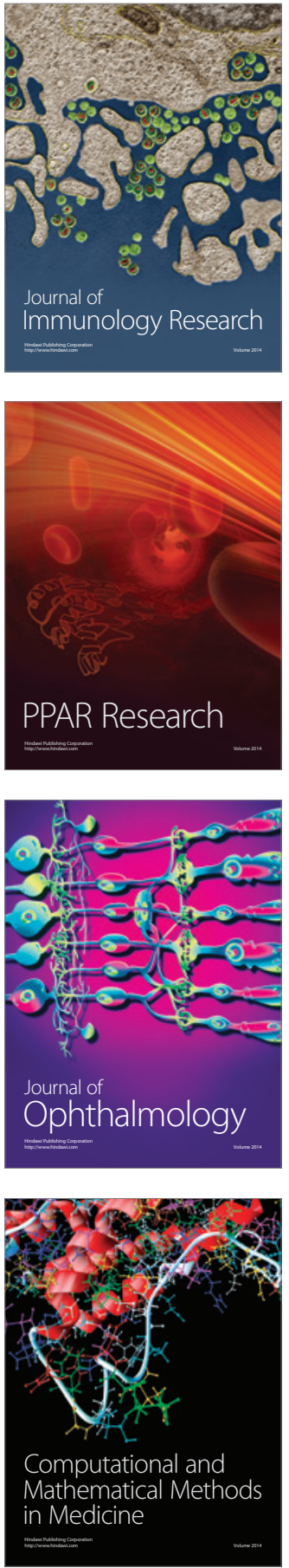

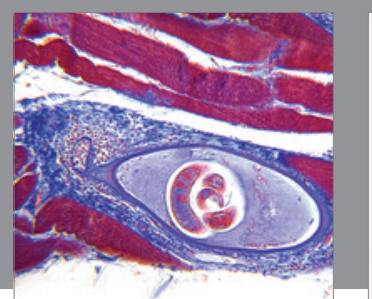

Gastroenterology Research and Practice

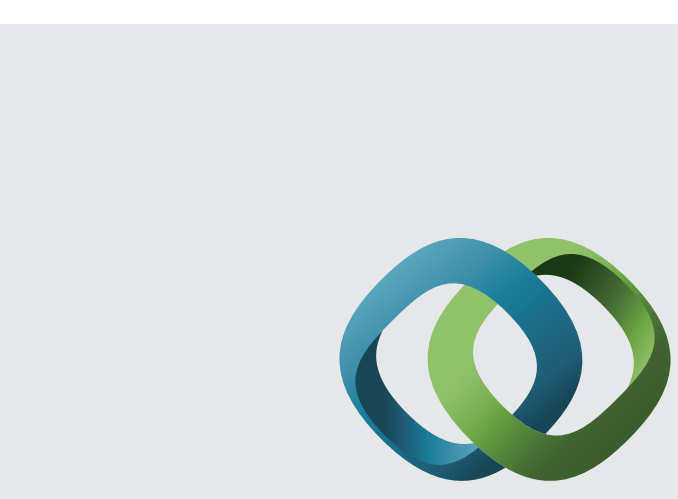

\section{Hindawi}

Submit your manuscripts at

http://www.hindawi.com
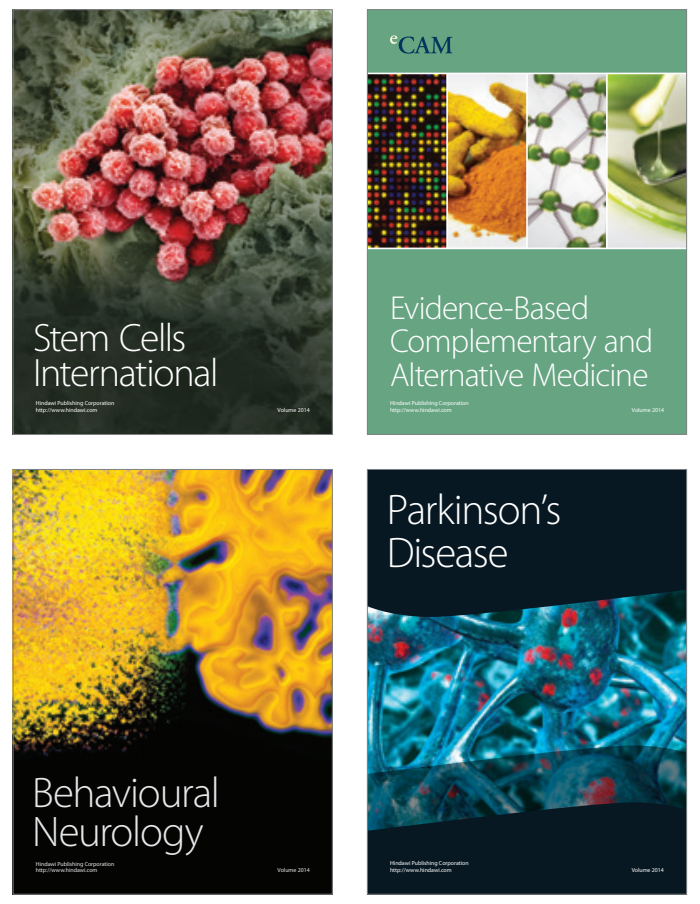
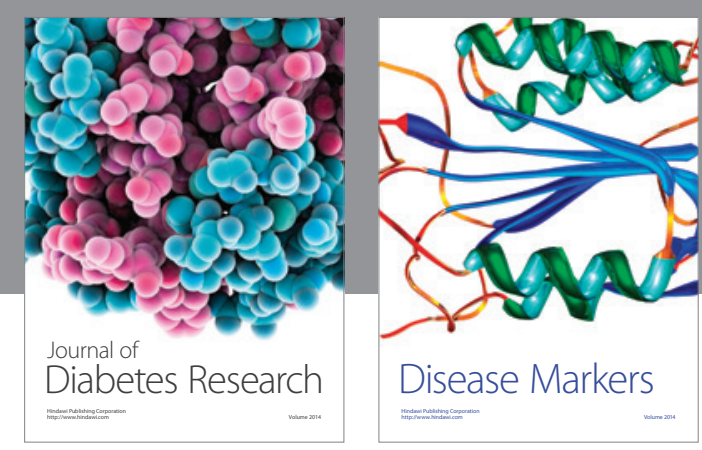

Disease Markers
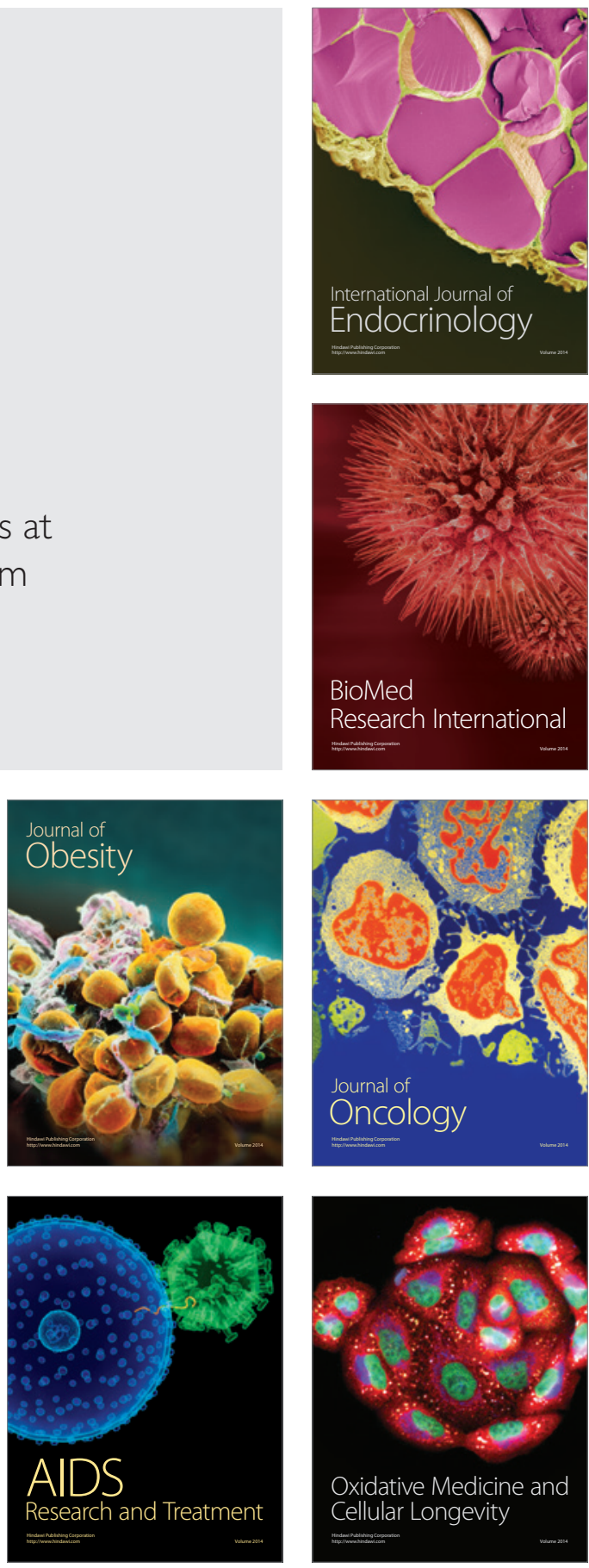